\title{
Chemotaxonomic Fingerprinting of Chilean Lichens Through Maldi and Electrospray Ionization Mass Spectrometry
}

\author{
Leonardo Silva Santos ${ }^{1 *}$, Maria del Pilar Camarantin Soriano ${ }^{1}$, Yaneris Mirabal- \\ Gallardo $^{1}$, Veronica Carrasco-Sanchez ${ }^{1}$, Fabiane Manke Nachtigall ${ }^{1}$, Iris Pereira ${ }^{1}$ and \\ Eugenia Pereira ${ }^{2}$ \\ ${ }^{l}$ Chemistry Institute of Natural Resources; Talca University; Talca, Maule - Chile. ${ }^{2}$ Departamento de Ciências \\ Geográficas; Universidade Federal de Pernambuco; Recife - PE - Brasil
}

\begin{abstract}
The aim of this work was to study a fast, new, sensitive, and simple method for the chemotaxonomic classification of Chilean lichens (Teloschistes chrysophthalmus, Ramalina farinacea, Usnea pusilla, Ramalina chilensis and Stereocaulon ramulosum) using MALDI-TOF-MS and UPLC-ESI(-)-MS data. Lichens soluble proteins fingerprints were acquired by MALDI-TOF-MS and they were analyzed by chemometric (PCA). Lichens organic extracts fingerprints were obtained by UPLC-ESI(-)-MS. MALDI-TOF-MS associated with chemometric analysis was used to detect new $\mathrm{m} / \mathrm{z}$ patterns of soluble proteins that were compared with Protein Data Bank of UnitPro. These data also permitted the satisfactory distinction among the families and species. UPLC-ESI(-)-MS fingerprints analyses of the organic extracts showed the presence of five major lichen compounds (atranorin, parietin, teloschistin, ramalinolic and usnic acids). In contrast to other techniques, MALDI-TOF-MS associated with chemometric analysis and UPLC-ESI(-)-MS provided a new, fast and sensitive method for chemotaxonomic characterization of lichens.
\end{abstract}

Key words: Chilean lichens, chemotaxonomic, fingerprint, MALDI-TOF-MS, UPLC-ESI(-)-MS

\section{INTRODUCTION}

There are approximately 28.000 lichen species worldwide (Lucking et al. 2009) that synthesize a great variety and diversity of secondary metabolites (Hidalgo et al. 1994; Huneck et al. 1996; Fournet et al. 1997; Huneck 1999; Müller 2001; Stocker-Wörgötter 2008). Several secondary metabolites identified and characterized from lichens show important biological and antioxidant activities (Barnes 2000; Rancan et al. 2002; Boustie and Grube 2005; Oksanen 2006; Pereira et al. 2007; Russo et al. 2008; SchmedaHirschmann et al. 2008; Molnár and Farkas 2010;
Shukla et al. 2010; Ghorbani et al. 2012; Manojlovic et al. 2012; Cuellar et al. 2013). Polysaccharides (as pectins) and lipids have also been detected in lichens (Olafsdottir and Ingólfsdottir 2001; Behera et al. 2005; Sassaki et al. 2005; Omarsdottir et al. 2007; Gielwanowska and Olech 2012). However, there is not much information reported about the presence of proteins in lichens (Fahselt 1980; Gorin and Iacomini 1985; Honegger and Bartnicki-Garcia 1991; Da Silva et al. 1993). For taxonomic determination of lichens, the content of secondary metabolites has been commonly used. These compounds are reasonably invariable within the

\footnotetext{
*Author for correspondence: 1ssantos@utalca.cl
} 
same species and most of them are exclusive of these organisms (Quilhot et al. 1987; Eifler-Lima et al. 2000). Lichen chemotaxonomy identification is frequently carried out through the use of one or more techniques as color reactions, thin layer chromatography (TLC), fluorescence, gas chromatography-mass spectrometry (GC-MS), high performance liquid chromatography (HPLC), Nuclear Magnetic Resonance (NMR), infrared (IR), Matrix-Assisted Laser Desorption Ionization Mass Spectrometry (MALDI-MS) (Honda and Vilegas 1998; Carbonero et al. 2001; Alcantara et al. 2007; Rustichelli et al. 2008), etc. For all these techniques, the accurate delimitation of species is not obvious because the lichens are in constant evolution in response to environmental parameters (Clerc 1998; Leavitt et al. 2011; Lumbsch et al. 2011).

In recent years, MALDI has become a powerful tool due to its sensitive, ease in use and achievable mass range, allowing measurement of metabolites, lipids, peptides, proteins, etc on the same instrument (Krishnamurthy 1996; Vaidyanathan et al. 2002; Santos et al. 2004; Catharino et al. 2005; Nanni et al. 2007; Rustichelli et al. 2008; Gustafsson et al. 2011; Radebe et al. 2013). Analyses of samples without any pre-treatment generally give large amount of information, often with a high degree of similarity, which cannot be interpreted by visual examination. Then, chemometrics can be a useful tool to extract hidden information of data, in particular, Principal Component Analysis (PCA) (Belton et al. 1998; Weinmann et al. 2003; Peña-Méndez et al. 2005; Brandt and Ehmann 2010; Scotti et al. 2010; Ohmenhaeuser et al. 2013). The application of chemometric is increasing as a need to cover more areas of research (Pomerantsev and Rodionova 2010). The chemometric analyses have been used in food investigations, plant extracts and clinical chemistry (Howells et al. 1992; Defernez et al. 1995; Vogels et al. 1996; Ellis et al. 2007; Trygg et al. 2007; Lai et al. 2010; Aouidi et al. 2012). Up to now, a protocol of sample preparations for MALDI analysis of lichen proteins is not reported, as well as no content information about the type of proteins present in lichen species is available. This work was carried out to develop an alternative, simple and rapid method for the chemotaxonomy identification of lichen, which comprised protein and secondary metabolites analyses associated to morphological and reproductive characters description of Chilean lichens with the purpose to delimit taxonomically different species.

\section{MATERIAL AND METHODS}

\section{Lichen Collection and Taxonomic Determination}

Lichen samples of five species were collected from Region del Maule in Chile during July 2011 (Fig. 1), which included Ramalina farinacea, Usnea pusilla, Ramalina chilensis and Stereocaulon ramulosum from El Colorado (38³8"53' S, 71'14"54' W: $444 \mathrm{msnm})$ and Teloschistes chrysophthalmus from Talca

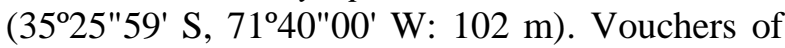
collected samples were deposited in the Lichen Herbarium of the Talca University and included latitude, longitude, altitude and substrate type (vouchers numbers 301, 302, 303, 304, 305, 306, 307, 308, 309 and 310).

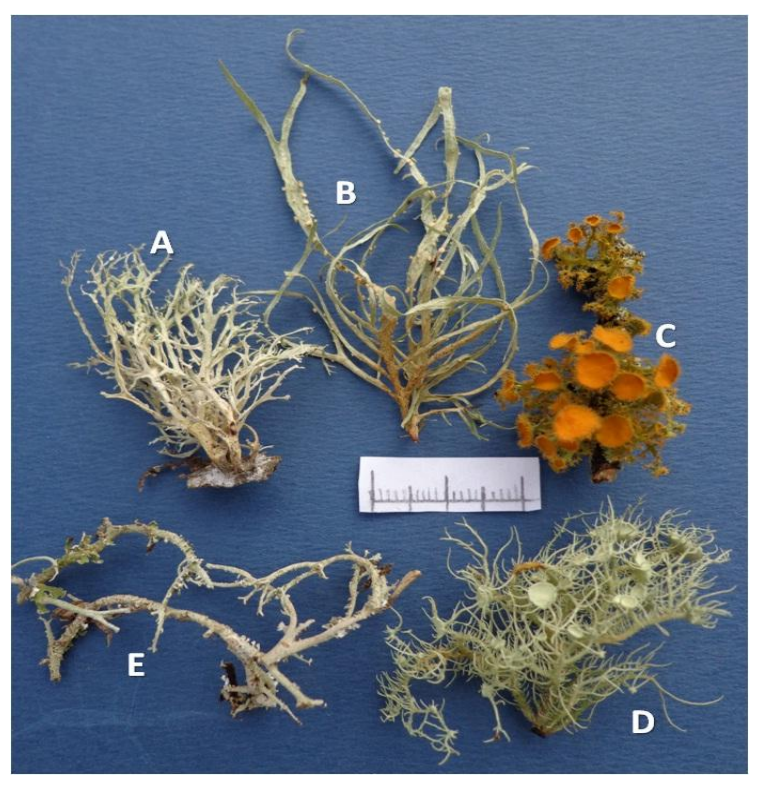

Figure 1 - Studied lichen species. Ramalinaceae Family: A) Ramalina farinacea (L.) Ach., and B) Ramalina chilensis Bert. Ex Nyl. Teloschistaceae Family: C) Teloschistes chrysophthalmus (L.) Th. Fr. Parmeliaceae Family: D) Usnea pusilla (Räsänen) Räsänen. Stereocaulaceae Family: E) Stereocaulon ramulosum (Sw.) Rausch. The scale represents $2 \mathrm{~cm}$.

Some morphological and reproductive characters and spot tests were used in the taxonomic determination through $\mathrm{KOH}(\mathrm{K}) ; \mathrm{Ca}(\mathrm{OCl})_{2}(\mathrm{C})$; combination between $\mathrm{K}$ and $\mathrm{C}(\mathrm{KC})$ and paraphenylenediamine $(\mathrm{Pd})$, according to Asahina and Shibata (1954) (Table 1). 
Table 1 - Morphological, reproductive characters and spot tests of the studied lichen species.

\begin{tabular}{|c|c|c|c|c|}
\hline Lichen & Growth form & Apothecia & Spores & Spot tests \\
\hline $\bar{D}$ & frutic & Lecanorine & hyaline, uniseptate & Aedulla $\mathrm{K}$ \\
\hline A & fruti & predia & absent &,$- C+, K C+$ \\
\hline $\mathrm{E}$ & composed & Biatorine & $\begin{array}{l}\text { hyaline, spores } 3-5 \\
\text { (7) celled }\end{array}$ & $\begin{array}{l}\text { Medulla K-,KC-, C-, Cortex and medulla Pd+ } \\
\text { first yellow, then red }\end{array}$ \\
\hline & fruticose & Lecanorine & hyaline, polarilocular & Thallus $\mathrm{K}+$ purple, C-, KC-, Pd- \\
\hline & fruticose & Lecanorine & hyaline, simple & Medula K-, C+ yellow, KC-, Pd+ \\
\hline
\end{tabular}

A) Ramalina farinacea (L.) Ach., B) Ramalina chilensis Bert. Ex Nyl. C) Teloschistes chrysophthalmus (L.) Th. Fr. D) Usnea pusilla (Räsänen) Räsänen. E) Stereocaulon ramulosum (Sw.) Rausch.

\section{Proteins and Organics Extractions}

Extractions were carried out in an ultrasonic bath (Elmasonic One, Ultrasonic cleaning unit, Elma, Germany). The extractions were performed at constant temperature $\left(24^{\circ} \mathrm{C}\right)$ for $2 \mathrm{~h}$. Soluble proteins of each lichen species were obtained using $250 \mathrm{mg}$ of fresh thallus by maceration in double distilled water $(1.0 \mathrm{~mL})$. The aqueous extracts of proteins were centrifuged at $4000 \mathrm{rpm}$ for $30 \mathrm{~min}$. (Table Top centrifuge PLC-05, Germany); the supernatant was again centrifuged for $30 \mathrm{~min}$. The total soluble proteins obtained were frozen in freezer and then lyophilized (Freezone 6 Freeze Dry System, Labconco, USA). Each lichen sample was successively extracted with diethyl ether, chloroform and acetone. The extracts were concentrated, weighed and kept in desiccators. The solvents used were obtained from Merck.

\section{MALDI-TOF MS}

A $1.0 \mu \mathrm{L}$ aliquot of soluble proteins sample was hand-spotted on a target type Anchorchip small $(400 \mu \mathrm{m})$ and dried by air. Then, $1.0 \mu \mathrm{L}$ of matrix solution (cinapinic acid) was added on the top of the dried samples and allowed to dry at room temperature $\left(24^{\circ} \mathrm{C}\right)$.

All the experiments were carried out on an Autoflex Speed MALDI-TOF mass spectrometer (Bruker Daltonics Flex Control) equipped with a nitrogen laser $(\lambda=337 \mathrm{~nm})$. The mass spectra were obtained in linear mode with an accelerating voltage of $20 \mathrm{kV}$. Mass range of $20-50 \mathrm{kDa}$ and 30-210 kDa were selected. Each spectrum was automatically collected in the positive ion mode as an average of 300 laser shots (30 laser shots at 10 different spot positions). Laser energy was selected to produce the threshold for ion production. Each assay was performed in triplicate and six MALDI spectra were acquired for each lichen species (three spectra of $20-50 \mathrm{kDa}$ and three spectra of $30-210 \mathrm{kDa})$. In total, ninety spectra were obtained.

\section{Chemometric analysis}

After processing of MALDI spectra, a data matrix for each lichen species was obtained. Due to the large number of data, a selection of a pattern of five relevant $\mathrm{m} / \mathrm{z}$ values was performed. The average of 20 spectra obtained by MALDI-MS for each sample, normalized with the flex Control Analysis 3.3 software were exported to the statistical software $\mathrm{R}$ version 2.12.2 (The Foundation for Statistical Computing, Vienna, Austria) in order to perform the principal components (PCA).

\section{LC Separation}

Methanol of HPLC grade was purchased from Merck SA and acetic acid were used without previous purification. Deionized water was obtained from a Purelab classic (Elga, Labwater, UK). Chromatographic separations were performed on a Poroshell 120 C18 column (4.6 mm x $50 \mathrm{~mm}$ id, $2.7 \mu \mathrm{m}$; Agilent, USA) using an Ultimate 3000 UHPLC focused (Bruker Daltonics) equipped with a PDA 3000 detector. Isocratic solvents system, $\mathrm{MeOH}, \mathrm{H}_{2} \mathrm{O}$, acetic acid (80:19.5:0.5, v/v) was used (Legaz and Vicente 1983). The column temperature was maintained at room temperature $\left(18^{\circ} \mathrm{C}\right)$. The flow rate was 1.0 $\mathrm{mL} / \mathrm{min}$. The extracts were diluted at $1.0 \mathrm{mg} / \mathrm{mL}$. Volume of injection was $20 \mu \mathrm{L}$. Detection was performed using both UV absorbance detector at $254 \mathrm{~nm}$ and ion trap mass detector. In order to test the reproducibility of the chromatography system, samples were injected on the UPLC column in triplicate.

\section{UPLC-ESI(-)-MS}

The mass spectrometric data were collected using an ion-trap AmaZon SL (Bruker, Germany) equipment. The column eluent entered the source 
of the ESI-MS for continuous detection by MS. The ion trap scanned in the $100-850 \mathrm{~m} / \mathrm{z}$ range and the maximum accumulation time for the ion trap was set at $200 \mathrm{~ms}$. The optimum values of the ESIMS parameters were: capillary voltage, $-4.0 \mathrm{kV}$; drying gas temperature, $220^{\circ} \mathrm{C}$; drying gas flow, $5.0 \mathrm{~L} / \mathrm{min}$; and nebulizing gas pressure of $8.0 \mathrm{psi}$. The instrument was controlled by trapControl 7.0 software from Bruker Daltonics and the data were processed by DataAnalysis 4.0 software from Bruker Daltonics.

\section{RESULTS}

\section{Taxonomic Determination}

The representatives of Ramalinacea, Teloschistaceae and Usneaceae families presented lecanorine apothecia and shared the growth form and reproduction modality, except $R$. farinacea that was reproduced by soredia. $S$. ramulosum was characterized by presenting thallus and apothecia biatorine (Table 1). The spot tests for Ramalina species were chemically similar, but the $\mathrm{KC}$ and Pd tests for $U$. pusilla were different. $T$. chrysophhalmus and $S$. ramulosum presented distinct chemical reactions and also showed differences in the types of spores (Table 1).

\section{MALDI-TOF-MS}

In total, 15 samples (three of each species) of lichens were analyzed. Mass spectra fingerprints of lichen soluble proteins from the five Chilean lichen species showed a characteristic pattern for each one (Fig. 2). Under these conditions, reproducible mass spectra of lichens were obtained. In the mass spectra, the peaks of the high and major intensities were observed in the $\mathrm{m} / \mathrm{z}$ region $30-210 \mathrm{kDa}$. The $\mathrm{m} / \mathrm{z}$ pattern of soluble proteins of lichen species were compared with the Data Bank of UnitPro, which showed that these registers were not included in this Data Bank. Because of the high similarity of the mass spectra in each species, where the intensities of the individual peaks only varied a little, and where there was a large number data $(\mathrm{m} / \mathrm{z}$ values), chemometric analysis was applied in an attempt to extract the underlying information contained in the spectra.
A
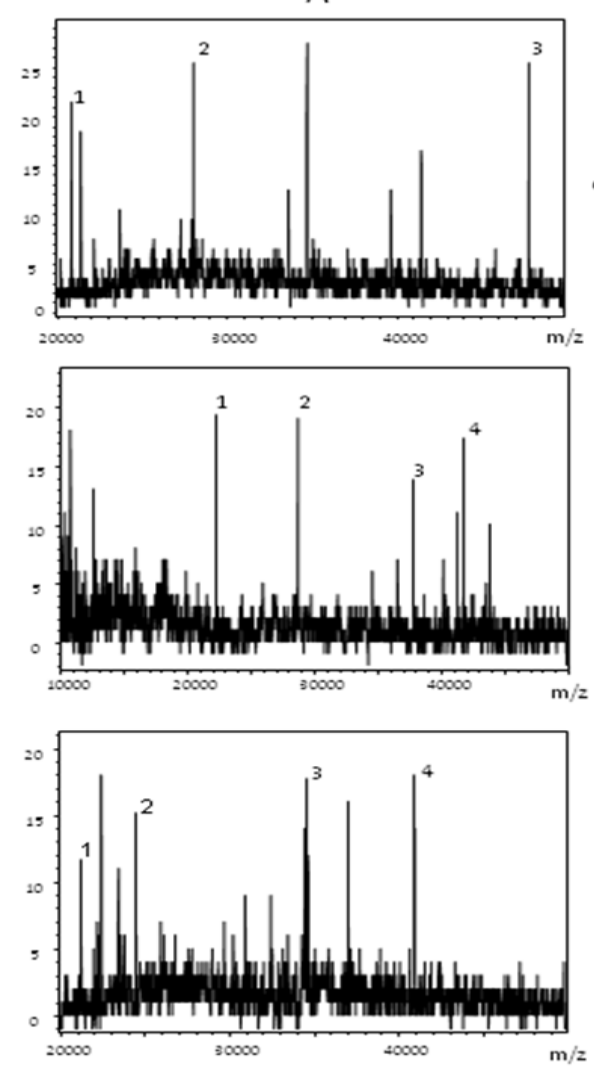

B
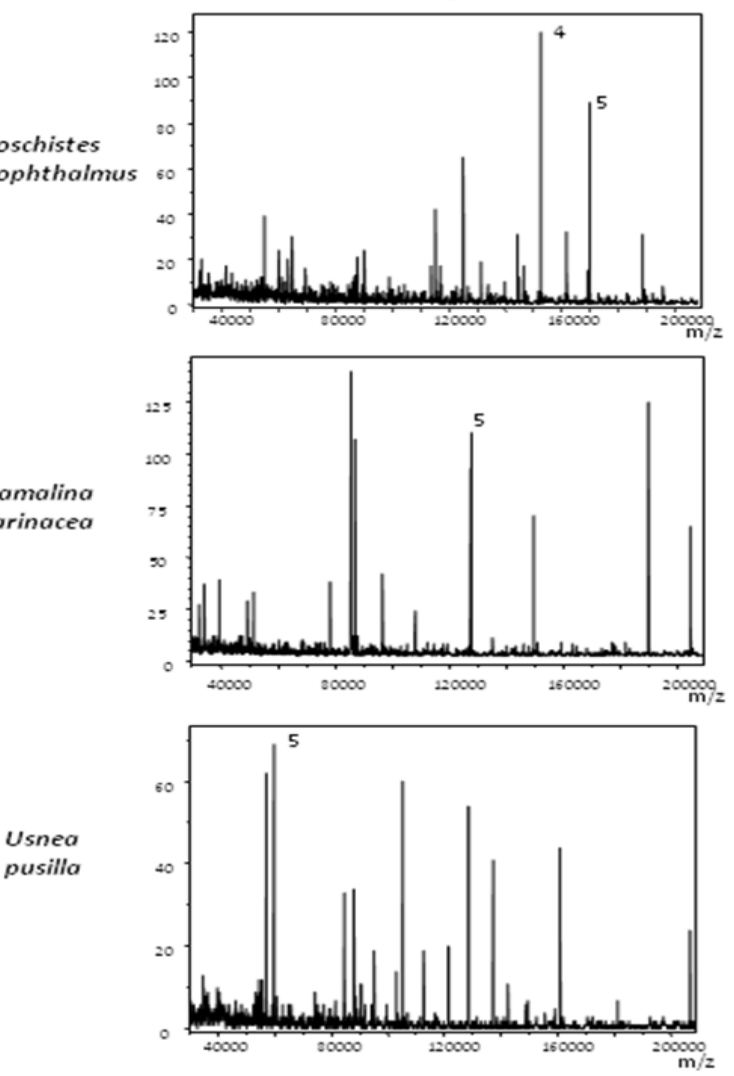
A
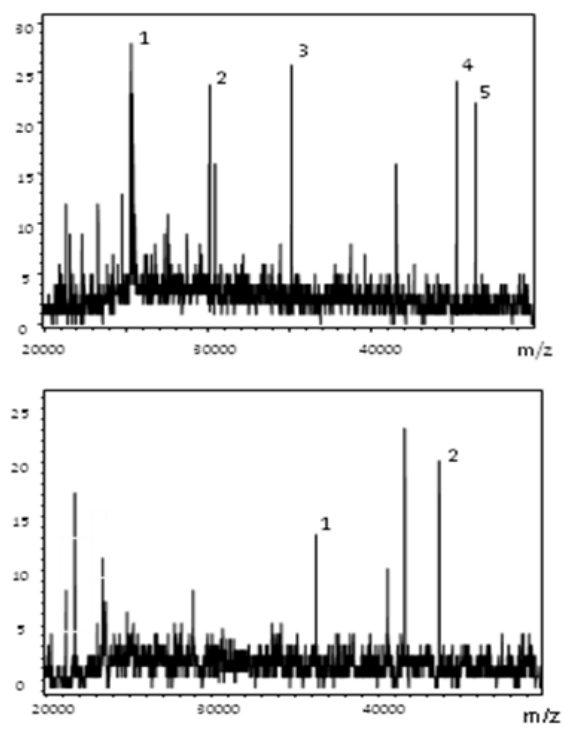

I: Lichens Protein profiles obtained in 20-50 kDa
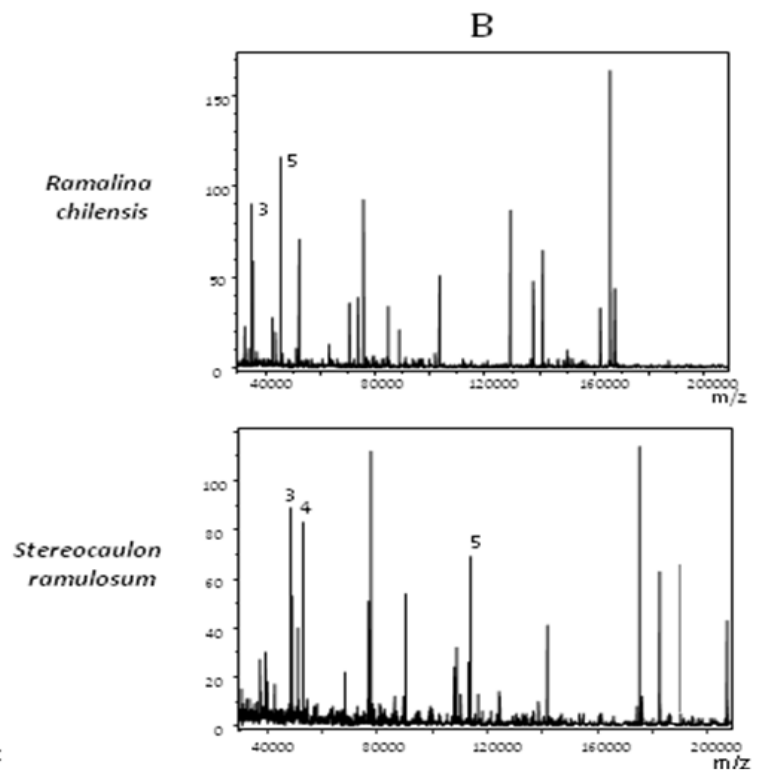

II: Lichens Proteins profiles obtained in 30- $210 \mathrm{kDa}$.

Figure 2 - Lichens Protein fingerprints obtained in 20-50 kDa and in 30-210 kDa.

\section{Chemometric analysis}

PCA was performed on the matrix data of lichens MALDI-TOF spectra. Due to the large number of data, a selection of a pattern of five relevant $\mathrm{m} / \mathrm{z}$ values was performed. This analysis showed a PCA characteristic pattern of reproducibility for each studied lichen species. PCA for MALDI-
TOF-MS data showed the separation of the lichens into families. Parmeliaceae and Ramalinaceae families were located on the upper first quadrant while Teloschistaceae family was located on the upper second quadrant. Stereocaulaceae was located on the bottom of the third quadrant (Fig. $3)$.

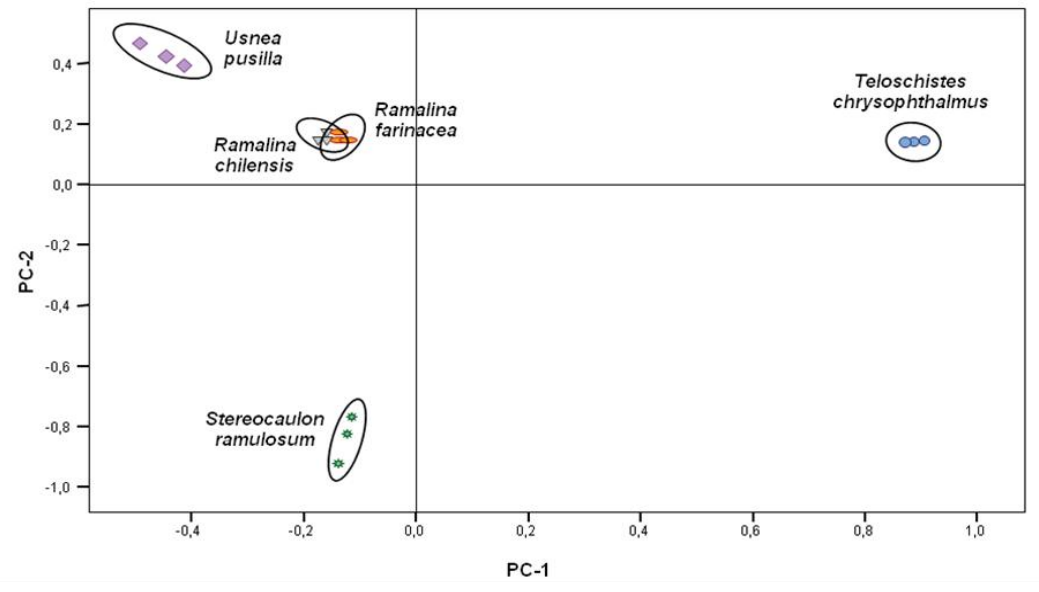

Figure 3 - PCA score plot of all lichens analyzed by MALDI-MS with lichen family distinction.

\section{UPLC-ESI(-)-MS}

UPLC chromatograms of lichen organic extracts were obtained in short analysis time with good resolution of the peaks. The lichen organic extracts fingerprints showed unique profiles and gave an idea of the number of major lichen compounds (Table 2 and Fig. 4). For example, Figure 5 showed that the acetone extract fingerprint of $U$. pusilla contained two main compounds (usnic acid and atranorin) identified by ESI(-)-MS/MS. 
Table 2 - Detected Compounds by UPLC-ESI (-)-MS.

\begin{tabular}{|c|c|c|c|}
\hline Lichen & Diethyl ether extract & Chloroformic extract & Acetonic extract \\
\hline \multirow{2}{*}{ T. chrysophthalmus } & Parietin $m / z 283$ & \multirow{2}{*}{ Telochistin $m / z 299$} & Telochistin $m / z, 299$ \\
\hline & Usnic acid $m / z 343$ & & Parietin $m / z 283$ \\
\hline \multirow{2}{*}{ R. chilensis } & Usnic acid $m / z, 343$ & Usnic acid $m / z 343$ & Usnic acid $m / z 343$ \\
\hline & Ramalinolic acid $m / z 431$ & Ramalinolic acid $m / z 431$ & Ramalinolic acid $m / z 431$ \\
\hline \multirow{2}{*}{ U. pusilla } & Usnic acid $m / z 343$ & Usnic acid $m / z, 343$ & Usnic acid $m / z 343$ \\
\hline & Atranorin $m / z 373$ & Atranorin $m / z 373$ & Atranorin $m / z 373$ \\
\hline \multirow{2}{*}{ R. farinacea } & Usnic acid $m / z 343$ & Usnic acid $m / z 343$ & Usnic acid $m / z 343$ \\
\hline & Protocetraric acid $\mathrm{m} / \mathrm{z} 373$ & Protocetraric acid $\mathrm{m} / \mathrm{z} 373$ & - \\
\hline S. ramulosum & Atranorin $m / z 373$ & - & Atranorin $m / z 373$ \\
\hline
\end{tabular}<smiles>CC(=O)C1=C(O)C=C2Oc3c(C(C)=O)c(O)c(C)c(O)c3C2(C)C1=O</smiles>

Usnic acid<smiles>[Y4]CCCc1cc(O)c(OC(=O)c2c(O)cc(OC)cc2CCC)c(O)c1C(=O)O</smiles><smiles>COc1cc(O)c2c(c1)C(=O)c1cc(C)cc(O)c1C2=O</smiles>

Parietin<smiles>CC(=O)c1c(C)cc(OC(=O)c2c(C)cc(O)c(C=O)c2O)c(C(C)=O)c1O</smiles>

Atranorin<smiles>COc1cc(O)c2c(c1)C(=O)c1cc(CO)cc(O)c1C2=O</smiles>

Telochistin

Figure 4 - Lichen compounds detected by UPLC-ESI (-)-MS.

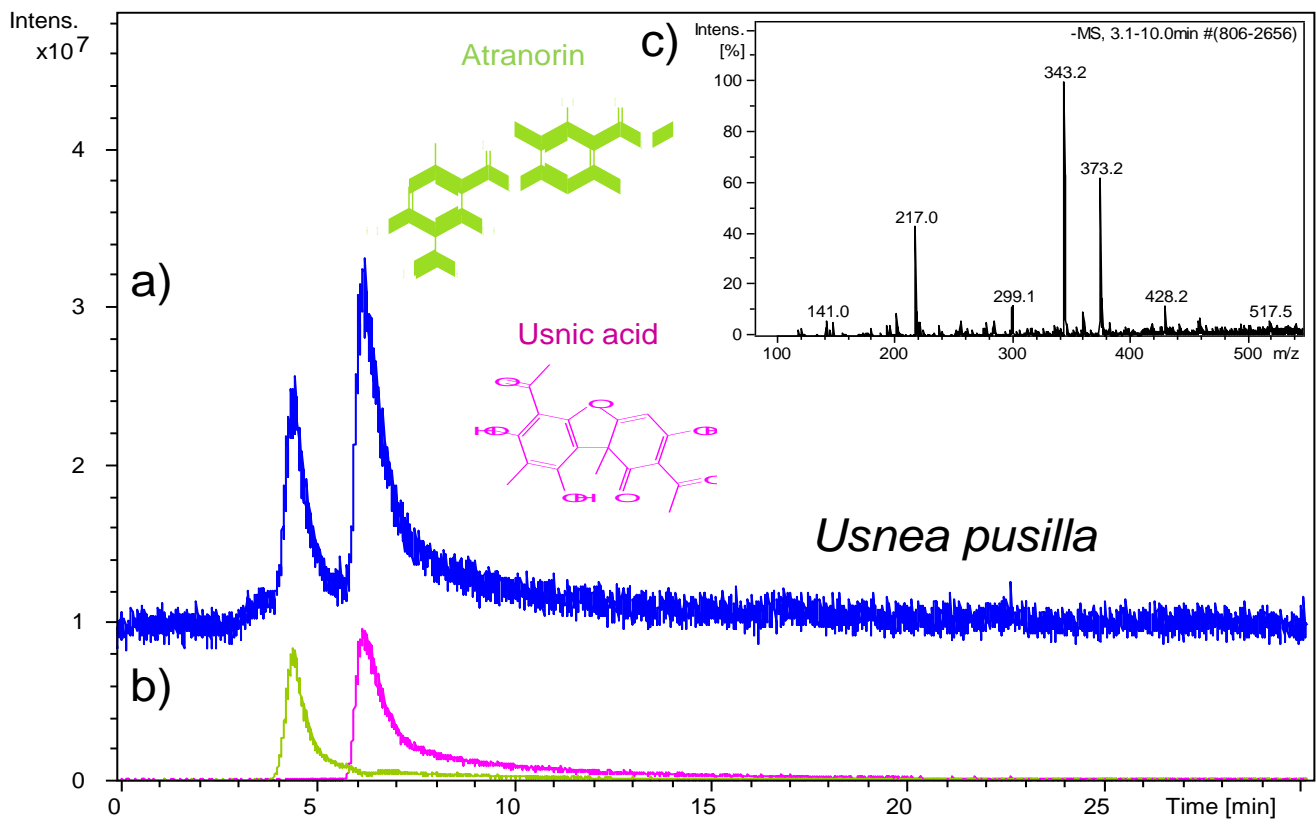

Figure 5 - Representative acetone extract fingerprint of Usnea pusilla. a) UHPLC-ESI-MS chromatogram showed two main compounds (usnic acid and atranorin) identified by ESI-(-)-MS/MS. b) Extracted ion chromatograms of $m / z 343$ (pink) and $m / z 373$ (green). c) Figure shows the ions for usnic acid $(\mathrm{m} / \mathrm{z}, 343)$ and atranorin $(\mathrm{m} / \mathrm{z} 373)$. 


\section{DISCUSSION}

There is a growing interest in phylogenetic studies and it sometimes is used as an advantageous tool in modern taxonomy but this to become reality, a huge database is required containing the signature sequences of all the species. This would need many years of research (Lucking 2009; Lumbsch et al. 2011). Hence, the chemotaxonomy classification is widely accepted as an important part of taxonomic studies (Honda and Vilegas 1998; Vitikainen 2001; Frisvad et al. 2008; Crespo et al. 2010; Tell et al. 2012; Lin 2013).

Figure 2 shows typical and distinguishable MALDI-MS in the positive ion mode of the extracts of each of the lichen species. As shown in Figure 2AI, the most characteristic and abundant ions were that of $m / z 24.410,27.987$, and 47.627. An expansion of the $m / z$ region, which had the main proteins of lichens (Fig. 2AII), showed two additional ions of $\mathrm{m} / \mathrm{z}, 152.787$ and 169.955 .

These ions were characteristic for $T$. chrysophthalmus. Figures 2BI and 2BII were representative for $R$. farinacea showing characteristic ions of $\mathrm{m} / \mathrm{z} 22.050,28.547$, (37559, 41.281) and 127.341. U. pusilla presented four characteristic ions in the range of $20-40 \mathrm{kDa}$ of $\mathrm{m} / \mathrm{z} 21.245,24.365,34.512$, and 40.471. Furthermore, several other ones between 80-120 $\mathrm{kDa}$ were characteristic for $U$. pusilla. When comparing $R$. chilensis (Fig. 2D) with $R$. farinacea (Fig. 2B), the ions of $m / z 25.290,30.074,35.106$, 45.187 , and 46.353 were observed. Figure $2 \mathrm{E}$ showed the characteristic ions for $S$. ramulosum of $\mathrm{m} / \mathrm{z}$ 36.257, 43.747, 49.268, 53.772 and 113.286. To test chemometrically, the distinctiveness of the MALDI-MS, PCA was employed. The PCA plot (Fig. 3), which covered $94 \%$ of the total data variance placed the samples into four well-defined groups comprised of the different species lichens.

\section{CONCLUSIONS}

Although the number of lichen species in this work was not very extensive, these preliminary results showed a new perspective of chemotaxonomic analysis in lichens. The PCA scores plot showed separation of the families, and Ramalina and Usnea species were located on the most positive side of PC2 axis, indicating a close relationship between these species. An overlapping of Ramalina species was observed, which showed that it belonged to the same family, whereas others species appeared in different quadrants, suggesting that the separation occurred due to each species containing different types of proteins. MALDI-TOF-MS together with chemometric analysis could be an excellent tool to obtain a fast method for the chemotaxonomic classification of lichens, which could be useful to identify the unknown lichen species.

UPLC-ESI(-)-MS of lichen organic extracts showed the main lichen compounds in the studied species. These results together with morphological, reproductive and protein data strengthened the new proposed method. Thus, this work presented preliminary results about of the protein content of lichen species and it envisaged in future to increases the data about the protein content for different lichen species.

\section{ACKNOWLEDGMENTS}

This work was funded by CONICYT (MEC 80100016), InnovaChile CORFO (Code FCR-CSB 09CEII-6991), FONDECYT 11130086, PIEI-QUIBIO (UTalca), Project Anillo ACT-1107, CNPq and FACEPE.

\section{REFERENCES}

Aouidi F, Dupuy N, Artaud J, Roussos S, Msallem M, Gaime IP et al. Rapid quantitative determination of oleuropein in olive leaves (Olea europaea) using mid-infrared spectroscopy combined with chemometric analyses. Ind Crops Prod. 2012; 37: 292-297.

Alcantara GB, Honda NK, Ferreira MMC, Ferreira AG. Chemometric analysis applied in ${ }^{1} \mathrm{H}$ HR-MAS NMR and FT-IR data for chemotaxonomic distinction of intact lichen samples. Anal Chim Acta. 2007; 595: 38.

Asahina Y, Shibata S. Chemistry of Lichen substances. 1a Ed. Tokio: Edition Tokyo, 1954, 245p.

Barnes J. Pharmacognosy in the 21st centur. Pharm J. 2000; 264: 701-703.

Behera BC, Verma N, Sonone A, Makhija U. Evaluation of Antioxidant Potential of the Cultures Mycobiont of a Lichen Usnea ghattensis. Phytother Res. 2005; 19: 58-64.

Belton PS, Colquhoun IJ, Kemsley EK, Delgadillo I, Roma P, Dennis MJ et al. Application of Chemometrics to the H-1 NMR spectra of apple juices: discrimination between apple varieties. Food Chem. 1998; 61: 207-213. 
Boustie J, Grube M. Lichens - a promising source of bioactive secondary metabolites, Plant Genet Resour. 2005; 3: 273-278.

Brandt H, Ehmann T. Toward Prediction: Using Chemometrics for the Optimization of Sample Preparation in MALDI-TOF MS of Synthetic Polymers. Anal Chem. 2010; 82: 8169-8175.

Carbonero ER, Sassaki GL, Stuelp PM, Gorin PA, Woranovicz-Barreira SM, Iacomini M. Comparative studies of the polysaccharides isolated from lichenized fungi of the genus Cladonia: significance as chemotypes. FEMS Microbiol Lett. 2001; 194: 6569.

Carrasco H, Espinoza L, Quilhot W. Depsides and triterpenes in Pseudocyphellaria coriifolia (lichens) and biological activity against Trypanosoma cruzi. Nat Prod Res. 2013; 27: 1607-1610.

Catharino RR, Marques LA, Santos LS, Baptista AS, Glória EM, Calori-Domingues MA et al. Aflatoxin Screening by MALDI-TOF Mass Spectrometry. Anal Chem. 2005; 77: 8155-8157.

Clerc P. Species concepts in the genus Usnea (lichenized Ascomycetes). Lichenologist. 1998; 30: 312-340.

Crespo A, Kauff F, Divakar PK, Del Prado R, PérezOrtega S, Amo $G$ et al. Phylogenetic generic classification of parmelioid lichens (Parmeliaceae, Ascomycota) based on molecular, morphological and chemical evidence. Taxon. 2010; 59: 1735-1753.

Cuellar MF, Rubio CL, Quiñonez NS, Montenegro IV, Salas CS, Da Silva HA et al. Carbohydrate, glycopeptide and protein components of the lichen Sticta sp. and effect of storage. Phytochemistry. 1993; 33: 547-552.

Defernez M, Kemsley EK, WILSON RH. Use of Infrared Spectroscopy and Chemometrics for the Authentication of Fruit Purees. J Agric Food Chem. 1995; 42: 109-113.

Eifler-Lima VL, Perry A, Sinbandhit S, Boustie J, Tomasi S, Schenkel E. NMR spectral data of salazinic acid isolated from some species of Parmotrema. Magn Reson Chem. 2000; 38: 472-474.

Ellis DI, Dunn WB, Griffin JL, Allwood JW, Goodacre R. Metabolic fingerprinting as a diagnostic tool. Pharmacogenomics. 2007; 8: 1243-1266.

Fahselt D. Alternative method for analyzing protein characterized. Bryologist. 1980; 83: 340-342.

Frisvad JC, Andersen B, Thrane U. The use of secondary metabolite profiling in chemotaxonomy of filamentous fungi. Mycol Res. 2008; 112: 231-240.

Fournet A, Ferreira ME, Rojas De Arias A, Torres De Ortiz S, Inchausti A, Yalaff G, et al. Activity of Compounds Isolated From Chilean Lichens Against Experimental Cutaneous Leishmaniasis. Comp Biochem Physiol, Part C: Pharmacol Toxicol Endocrinol. 1997; 116: 51-54.
Ghorbani A, Langenberger G, Sauerborn J. A Comparison of the wild food plant use knowledge of ethnic minorities in Naban River Watershed National Nature Reserve, Yunnan, SW China. J Ethnobiol Ethnomed. 2012; 8: 1-9.

Gielwanowska I, Olech M. New Ultrastructural and Physiological Features of the Thallus in Antarctic Lichens. Acta Biol Cracov. Ser Bot. 2012; 54: 40-52.

Gorin PAJ, Iacomini M. Structural diversity of Dgalacto-D-mannan components isolated from lichens having ascomycetous mycosymbionts. Carbohydr Res. 1985; 142: 253-267.

Gustafsson JOR, Oehler MK, Ruszkiewicz A, Mccoll SR, Hoffmann P. MALDI Imaging Mass Spectrometry (MALDI-IMS)-Application of Spatial Proteomics for Ovarian Cancer Classification and Diagnosis. Int J Mol Sci. 2011; 12: 773-794.

Hidalgo ME, Fernández E, Quilhot W, Lissi E. Antioxidant activity of depsides and depsidones. Phytochemistry. 1994; 37: 1585-1587.

Honda NK, Vilegas W. A química dos liquens. Quim Nova. 21: 110-125.

Honegger R, Bartnicki-Garcia S. Cell wall structure and composition of cultured mycobionts from the lichens Cladonia macrophylla, Cladonia caespiticia, and Physcia stellaris (Lecanorales, Ascomycetes). Mycol Res. 1998; 95: 905-914.

Howells SL, Maxwell RJ, Peet AC, Griffiths JR. An Investigation of Tumor ${ }^{1} \mathrm{H} \quad$ Nuclear Magnetic Resonance Spectra by the Application of Chemometric Techniques. Magn Reson Med. 1992; 28: 214-236.

Huneck S, Yoshimura I. Identification of Lichen Substances, Springer-Verlag Berlin and Heidelberg GmbH \& Co. K, Germany. 1996.

Huneck S. The Significance of Lichens and Their Metabolites. Naturwissenschaften. 1999; 86: 559570.

Krishnamurthy T. Rapid identification of bacteria by direct matrix assisted laser desorption/ionization mass spectrometric analysis of whole cells, Rapid Commun Mass Spectrom. 1996; 10:1992-1996.

Lai YH, NI YN, Serge K. Authentication of Cassia seed on the basis of two-wavelength HPLC fingerprinting with the use of chemometrics. Chin Chem Lett. 2010; 21: 213-216.

Leavitt SD, Johnson L, St. Clair LL. Species Delimitation and Evolution in Morphologically and Chemically Diverse Communities of the LichenForming Genus Xanthoparmelia (Parmeliaceae, Ascomycota) in Western North America. Am J Bot. 2011; 98: 175-188.

Legaz ME, Vicente C. Endogenous Inactivators of Arginase, L-Arginine Decarboxylase, and Agmatine Amidinohydrolase in Evernia prunastri Thallus. Plant Physiol. 1983; 71: 300-302. 
Lin CK. The Lichen Genus Lobaria at Shenmi Lake, Northeastern Taiwan. Collection Res. 2013; 26: 3742.

Lücking R, Rivas-Plata E, Chaves JL, Umaña L, Sipman HJ. How many tropical lichens are there really?, 2009, p.399-417. In A. Thell, M.R.D. Seaward and T. Feuerer (eds.), Diversity of Lichenology, Anniversary volume, Bibl. Lichenol., Berlin-Stuttgart, Alemania.

Lücking R. Taxonomy: a discipline on the brink of extinction. Are DNA bar barcode scanners the future of biodiversity research? Arch Sci. 2009; 61: 75-88.

Lumbsch H T, Ahti T, Altermann S, Amo Da Paz G, Aptroot A, Bárcenas AP et al. One hundred new species of lichenized fungi: a signature of undiscovered global diversity. Phytotaxa. 2011; 18: 1-127.

Manojlovic NT, Vasiljevic PJ, Maskovic PZ. Chemical composition and antioxidant activity of lichen Toninia candida. Braz J Pharmacog. 2012; 22: 291298.

Molnar K, Farkas E. Current results on biological activities of lichen secondary metabolites: a review, $Z$ Naturforsch C. 2010; 65: 157-173.

Müller K. Activity of Compounds Isolated From Chilean Lichens Against Experimental Cutaneous Leishmaniasis. Pharmaceutically relevant metabolites from lichens. Appl Microbiol Biotechnol. 2001; 56: 916.

Nanni P, Parisi D, Roda G, Casale M, Belluzzi A, Roda E, Mayer L, Roda A. Serum protein profiling in patients with inflammatory bowel diseases using selective solid-phase bulk extraction, matrix-assisted laser desorption/ionization time-of-flight mass spectrometry and chemometric data analysis. Rapid Commun Mass Spectrom. 2007; 21: 4142-4148.

Ohmenhaeuser M, Monakhova YB, Kuballa T, Lachenmeier DW. Qualitative and Quantitative Control of Honeys Using NMR Spectroscopy and Chemometrics. Anal Chem. 2013: 1-9.

Oksanen I. Ecological and biotechnological aspects of lichens. Applied Microbiol Biotechnol. 2006; 73: 723 734.

Olafsdottir ES, Ingólfsdottir K. Polysaccharides from lichens: structural characteristics and biological activity. Planta Medica. 2001; 67: 199-208.

Omarsdottir S, Freysdottir J, Olafsdottir ES. Immunomodulating polysaccharides from lichen Thamnolia vermicularis var. subuliformis. Phytomedicine. 2007; 14: 179-184.

Peña-Méndez EM, Gajdošová D, Novotná K, PROŠEK P, HAVEL J. Mass spectrometry of humic substances of different origin including those from Antarctica: A comparative study. Talanta. 2010; 67: 880-890.
Pereira I, Amaro JM, Astudillo L, Padilla C, Lobos O, Santos LS. Assessment of antibacterial and antifungic activity in four species of Maule region in Chile. Proceedings of the 7th European Workshop of Biotechnologists of microalgae and other phototrophic organisms, Nuthetal, Germany. 2007.

Pomerantsev AL, Rodionova OY. Chemometric view on "comprehensive chemometrics." Chemom Intell Lab Syst. 2010; 103: 19-24.

Quilhot W, Leighton G, Flores E, Fernandez E, Peña W, Guzman G. Factores Exógenos y Endógenos determinantes de la Acumulación de Acido Usnico en Líquenes. Acta Farm Bonaerense. 1987; 6: 15-22.

Radebe N, Rode K, Pizzi A, Pasch H. Microstructure elucidation of polyflavonoid tannis by MALDI-TOFCID. J Appl Polym Sci. 2013; 127: 1937-1950.

Russo A, Piovano M, Lombardo L, Garbarino J, Cardile V. Lichen metabolites prevent UV light and nitric oxide-mediated plasmid DNA damage and induce apoptosis in human melanoma cells. Life Sci. 2008; 83: 468-474.

Rustichelli C, Visioli G, Kostecka D, Vurro E, Sanità Di Toppi L, Marmiroli N. Proteomic analysis in the lichen Physcia adscendens exposed to cadmium stress. Environ Pollut. 2008; 156: 1121-1127.

Santos LS, Haddad R, Höehr NF, Pilli RA, Eberlin MN. Fast Screening of Low Molecular Weight Compounds by Thin-Layer Chromatography and "On-Spot" MALDI-TOF Mass Spectrometry. Anal Chem. 2004; 76: 2144-2147.

Sassaki GL, Gorin PA, Reis RA, Serrato RV, Elífio SL, Iacomini M. Carbohydrate, glycolipid, and lipid components from the photobiont (Scytonema sp.) of the lichen Dictyonema glabratum. Carbohydr Res. 2005; 340: 1808-18017.

Schmeda-Hirschmann G, Tapia A, Lima B, Pertino M, Sortino S, Zacchino S. A New Antifungal and Antiprotozoal Depside from the Andean Lichen Protousnea poeppigii. Phytother Res. 2008; 22: 349355.

Scotti L, FERREIRA EI, Da Silva MS, Scotti MT. Chemometric Studies on Natural Products as Potential Inhibitors of the NADH Oxidase from Trypanosoma cruzi Using the VolSurf Approach. Molecules. 2010; 15: 7363-7377.

Shukla V, Joshi GP, RAWAT MSM. Lichens as a potential natural source of bioactive compounds: a review. Phytochem Rev. 2010; 9: 303-314.

Stocker-Wörgötter E. Metabolic diversity of lichenforming ascomycetous fungi: culturing, polyketide and shikimate metabolite production, and PKS gene. Nat Prod Rep. 2008; 25:188-200. 
Tell A, Crespo A, Divakar KPK, Kärnefelt I, Leavitt SD, Lumbsch HT, Seaward MRD. A review of the lichen family Parmeliaceae - history, phylogeny and current taxonomy. Nord J Bot. 2012; 30: 641-664.

Trygg J, Holmes E, Lundstedt T. Chemometrics in Metabonomics. J Proteome Res. 2007; 6: 469-479.

Vaidyanathan S, Kell DB, Goodacre R. Rapid, highthroughput microbial characterization by metabolite and protein profiling of whole cells using softionization mass spectrometry. Abstr Papers Am Chem Soc. 2002; 224: U199, 011-Biot.

Vitikainen O. William Nylander (1822-1899) and lichen chemotaxonomy. Bryologist. 2001; 104: 263267.
Vogels JTWE, Terwel L, Tas AC, Van Den Berg F, Dukel F, Van der Greef F. Detection of Adulteration in Orange Juices by a New Screening Method Using Proton NMR Spectroscopy in Combination with Pattern Recognition Techniques. J Agric Food Chem. 1996; 44: 175-180.

Weinmann W, Baumeister K, Kaufmann I, Przybylski M. Separation and characterization of humic acids from Antarctica by capillary electrophoresis and matrix-assisted laser desorption ionization time-offlight mass spectrometry: Inclusion complexes of humic acids with cyclodextrins. J Chromatogr $A$. 2003; 1014: 117-127. 